$$
\begin{aligned}
& \text { 震 } \\
& \text { 竞背市 }
\end{aligned}
$$

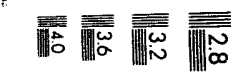

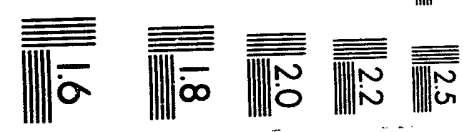



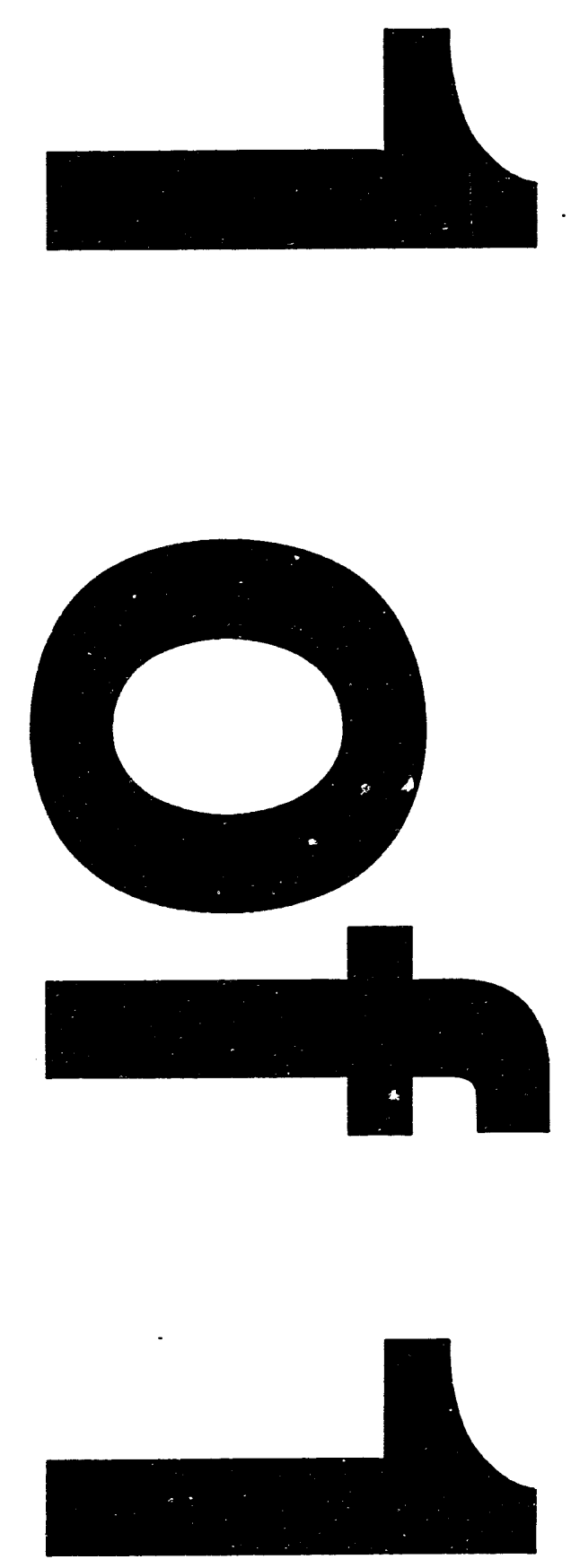


\section{Distillate Market Model Documentation Report}

December 1993

\section{Energy Information Administration}

Petroleum Marketing Division

Office of Oil and Gas

U.S. Department of Energy

Washington, DC 20585 
Reieased for Printing: February 25, 1994 


\section{Distillate Market Model Documentation Report}

\section{INTRODUCTION}

\section{Purpose of the Report}

The purpose of this report is to define the objectives of the Distillate Market Model (DMM), describe its basic approach, and to provide detail on model functions. This report is intended as a reference document for model analysts, users, and the general public. Documentation of the model is in accordance with EIA's legal obligation to provide adequate documentation in support of its models (Public Law 94-385, Section $57(\mathrm{~b})(2))$.

\section{Model Summary}

The DMM performs a short-term (6-to 9-month) forecast of demand and retail price for distillate fuel oil in the national U.S. market; it also calculates the end-of-month stock level during the term of the forecast. The model is used to analyze certain market behavior assumptions or shocks and to determine the effect on retail market price, demand, and stock level.

\section{Model Archival Citation}

The Distillate Market Model (DMM) is archived on IBM-compatible microfloppy disks and is available through the sponsoring office. The model contact is:

Charles Dale

U.S. Department of Energy

Energy Information Administration

office of oil and Gas

Petroleum Marketing Division

Publications and Analysis Branch

Mail Code: EI-432

Forrestal Bldg.

Room 2G-029

1000 Independence Ave., SW

Washington, DC 20585

Phone: (202) 586-1805

Fax: (202) 586-4913 


\section{Report Organization}

The remainder of this report is organized in the following manner: model purpose, (2) model rationale, (3) model structure, (4) properties of mathematical solution, (5) calibration and sensitivity analysis, (6) documentation of technical detail on model data and equations, and (7) appendices .

\section{MODEL PURPOSE}

\section{Model Objectives}

The DMM is to be used for policy analysis and general forecasting purposes and was developed for presentation at the state Heating Oil and Propane Program and the Winter Fuels conferences and also for the annual Distillate Fuel Oil Outlook article published in the Winter Fuels Report and the Petroleum Marketing Monthly. The model addresses very short-term monthly U.S. market responses at the national level. The model focuses on U.S. retail distillate demand and price and assesses market response to alternative scenarios and/or shocks, by providing very short-term (up to 9 months) forecasts of distillate demand, retail price, and end-ofmonth stock level. The model relies on the Short-Term Energy Outlook (STEO) mid-world oil price case to define a baseline and then uses assumptions on different possible market disturbances to assess market response on a monthly basis; the DMM differs substantially from the STEO because of a partial, rather than general, equilibrium approach to modelling petroleum product markets, because the DMM calculates a stock path rather than using an a priori choice, and because of the exclusive short-run focus of the DMM model. It has been used to forecast the effect of heating degree day and crude price changes on distillate prices and product supplied. The DMM also provides a framework to calculate stock levels from the forecasted demand and price variables.

\section{Model Input/Output}

The DMM uses both DOE and non-DOE data input sources. The non-DOE data came from two sources. Data Resources, Inc. (DRI) databases provided values, from the Bureau of Economic Analysis and the Bureau of Labor statistics, for general monthly national macroeconomic variables (including the industrial production index and the producer price index). The National Oceanic and Atmospheric Administration was the source for heating degree day information. The DOE historical data for crude oil prices, refinery variables, distillate demand, stock levels, and retail price cal.e from EIA publications: the Petroleum Marketing Annual/Monthly (various issues) and the Petroleum Supply Annual/Monthly (various issues). All forecasts for future values of the independent variables used in the DMM came from EIA's Short-Term Integrated Forecasting System (Energy Information Administration, 1993). 
Output from the DMM includes very short-term monthly forecasts of national demand, retail price, and stock levels of No. 2 distillate fuel oil.

\section{Relationship to Other Models}

The DMM interfaces directly with the Short-Term Integrated Forecasting System (STIFS) model by utilizing the mid-world oil price case forecast of distillate demand and retail price as the basis from which market perturbations will be analyzed. The model also takes projected values of No. 2 distillate fuel oil variables exogenously from STIFS: refinery production, field production, and net imports. Additionally, the model directly utilizes forecasts of certain macroeconomic and refinery variables from STIFS as inputs.

\section{MODEL OVERVIEW AND RATIONALE}

\section{Fundamental Assumptions}

The DMM is to be used to judge the effect of shocks or alternative behavior assumptions on the demand, price, and end-of-month stock level for retail No. 2 distillate fuel oil in the national economy. The theoretical basis for the model is the standard demand-supply approach used to determine the market effects of shifting demand and supply curves on a single product in an isolated market; it implicitly makes the assumption that all economic entities exhibit profit maximizing behavior. The model indirectly allows for feedback effects between price and demand over a monthly time frame. Although the model functions at a monthly frequency, conclusions are normally drawn from the model on a quarterly or semi-annual basis. The DMM uses recent historical market behavior as a pattern for predicting near-term future market responses.

The DMM is concerned with very short-term (i.e., 6- to 9-month) projections into the future. In order to make the analysis more tractable, a number of simplifying assumptions were made concerning the behavior of the distillate market; these include:

- Constant relative size of vehicle fleet using diesel fuel. Additionally, vehicle efficiency is assumed to be constant in the short-run due to the slow replacement of the current truck and automobile fleet.

- The No. 2 distillate fuel oil market is isolated from disturbances to other petroleum product markets. It is assumed that any significant interaction between the distillate market and other product markets leg., gasoline, jet fuel, residual fuel, and other 
petroleum products) would not occur within the timeframe of the forecast.

- Constant level of taxation. Taxes on No. 2 fuel oil and No. 2 diesel fuel have a direct effect on price and an indirect effect on demand. For the time frame of the forecast, it is assumed that any increased taxation will not cause serious market distortions and will be completely passed through to the retail level.

- The relative proportion of homes using No. 2 fuel oil for heating purposes remains constant. Additionally, furnace efficiency is assumed to be constant over the timeframe of the model projections.

- The spot purchases of No. 2 fuel oil by Non-Utility Generators will not distort the retail market. Most new cogeneration plants require Natural Gas as fuel; to reduce construction costs, these plants have minimal storage facilities for storing liquid heating fuels. During a prolonged cold spell, the natural gas service to these facilities may be interrupted, thus requiring a switch to No. 2 distillate as fuel.

- No change in refinery economic conditions. All scenarios were conducted under the assumption that refinery and production conditions do not radically change during the duration of the forecast. Net imports were also assumed to be exogenousiy determined.

The model makes no provision to distinguish between the types (e.g., diesel, heating fuel) or grade (e.g., low sulfur, high sulfur, dyed, etc.) of No. 2 distillate sold in the retail market.

The DMM allows market players to make pricing decisions based on historical price, demand, and stock patterns. The model assumes that market players make decisions on a monthly basis; although this may be somewhat of a long reference time frame, any analysis utilizing a more rapid decisionmaking process would be hampered by the lack of data availability at higher frequencies.

\section{Alternative Approaches}

The DMM is a time series model typical of a form used for the estimation of gasoline demand (see, for example, R. J. Sutherland, 1991). Crosssectional models of end user purchasing behavior were not considered because of the need to forecast market adjustments to possible shocks for longer than a single time period. The STIFS model was not used because of the desire not to limit the effects of weather on heating oil demand to the Northeast section of the country and also to estimate total. distillate demand in a single equation.

Prof. Tim Considine of Pennsylvania State University recently developed a short-term forecasting model for EIA (Task No. 92073, Contract No. DEAC01-89-EI21003). That model was not used here for several reasons: 
- The desire to model the distillate market as an isolated sector of the economy.

- The desire to avoid the problem of nonconvergence that can occur in multi-product models.

- The desire to estimate product supplied (demand) directly, rather than as an identity, in order to check the model's prediction of consumer behavior.

- The desire to focus on retail distillate prices rather than the wholesale prices contained in a production oriented model.

\section{MODEL STRUCTURE}

\section{Flow Diagram}


DISTILLATE ACTIVITY MARVET MODEL FLOW DIAGRAM

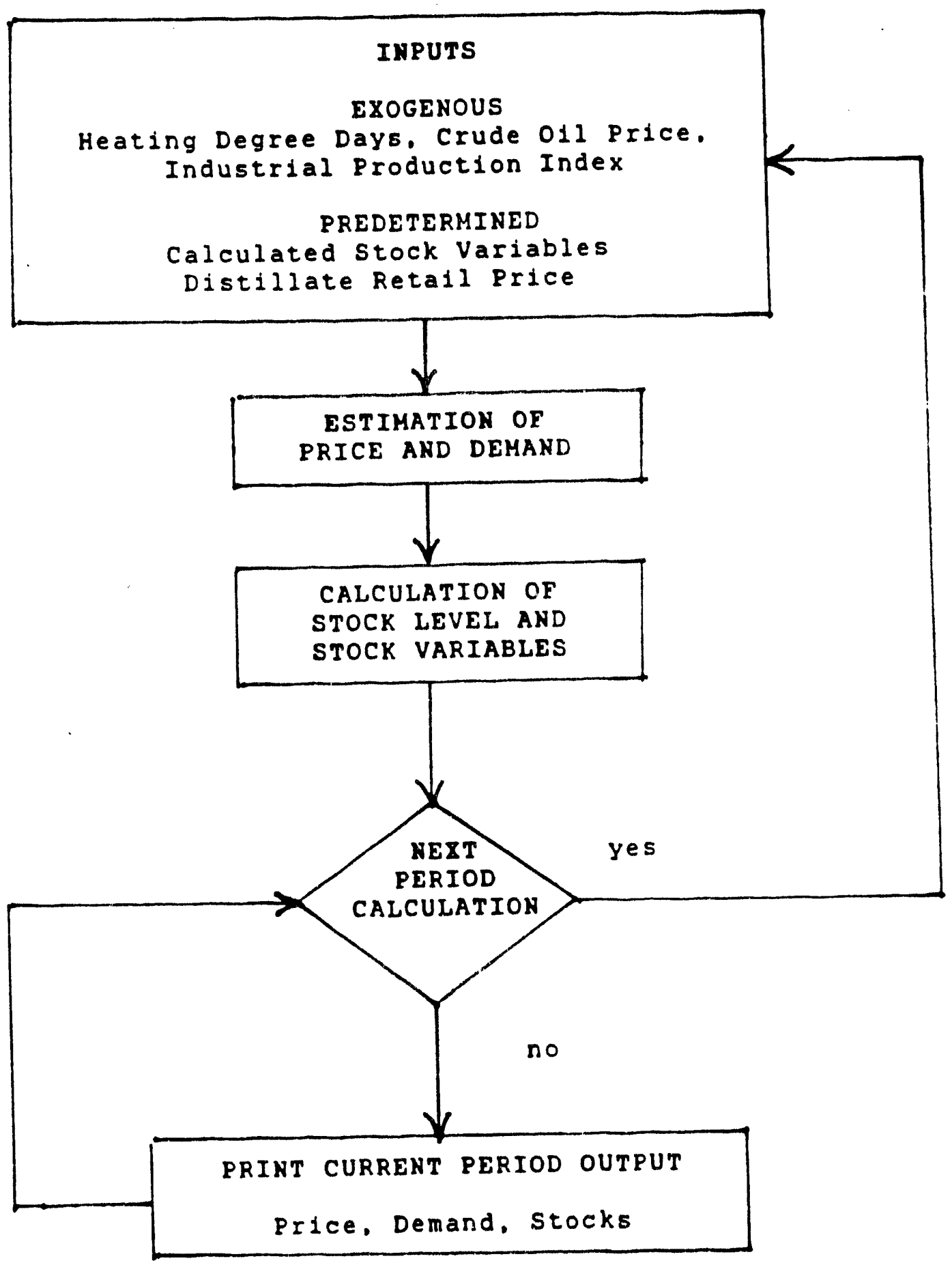

Energy Information Administration / Petroleum Marketing Division 
Solution of the DMM proceeds in a straightforward manner. The input variables are used as exogenous and predetermined variables for the independent estimation of demand and price. The model then algebraically calculates the projected stock level and other stock related variables used as inputs. The current period solution is printed and the model proceeds, if necessary, to the estimation for the next period.

\section{List of Computations and Equations}

The equation used by the model for the estimation of price is of the form:

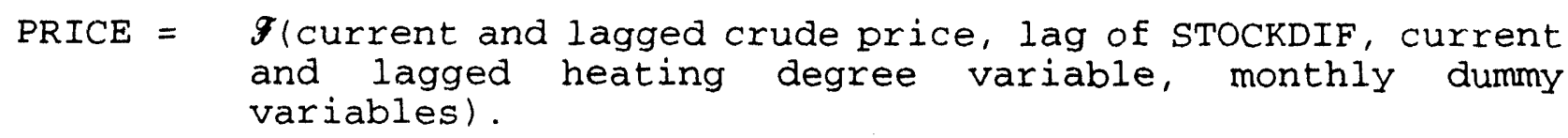

The actual estimated price equation is:

$$
\begin{aligned}
& \text { PRICE }_{t}=\boldsymbol{\alpha}_{0}+\boldsymbol{\alpha}_{12}{ }^{*} \text { CRUDEPR }_{\mathrm{t}}+\boldsymbol{\alpha}_{13}{ }^{*} \text { CRUDEPR }_{\mathrm{t}-1}+\boldsymbol{\alpha}_{14} \text { STOCKDIF }_{\mathrm{t}-1} \\
& +\boldsymbol{\alpha}_{15}{ } \mathrm{HDDSPSQ}_{t}+\boldsymbol{\alpha}_{16}{ }^{\star} \mathrm{HDDSPSQ}_{t-1}+\sum_{i=1}^{11} \boldsymbol{\alpha}_{1} \star \text { DUMMY }_{\mathrm{i}}
\end{aligned}
$$

The equation used by the model for the estimation of demand (product supplied) is of the form:

$$
\begin{aligned}
\text { DEMAND = } & \text { g(business cycle variable, current and lagged heating } \\
& \text { degree days, trend, Kuwait war dummy variables, monthly } \\
& \text { dummy variables). }
\end{aligned}
$$

The actual estimated deniand equation is:

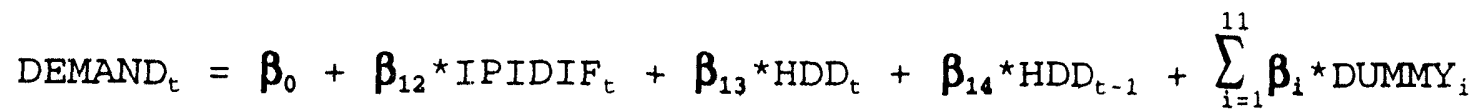

$$
\begin{aligned}
& +\boldsymbol{\beta}_{15} \star \text { DOAUG90 }+\boldsymbol{\beta}_{16}{ }^{\star D O D E C 90}+\boldsymbol{\beta}_{17}{ }^{\star T R E N D} \text { TR }_{t}
\end{aligned}
$$

where PRICE is the average No. 2 fuel oil price to residential customers deflated by the producer Price Index.

HDD is the mean deviation from normal heating degree days ${ }^{1}$.

${ }^{1} \mathrm{HDD}_{\mathrm{t}}=\left(\mathrm{HDDA}_{\mathrm{t}}-\mathrm{HDDN}_{\mathrm{t}}\right) /$ DAYS, where HDDA $\mathrm{H}_{\mathrm{t}}$ is the actual population weighted heating degree days for time period $t$ and $\mathrm{HDDN}_{\mathrm{t}}$ is the estimated 30 year average (1951 - 1980 basis) for each period. 


$$
\begin{aligned}
& \mathrm{HDDSPSQ}=\left\{\begin{array}{l}
\mathrm{HDD}^{\star *} 2 \text { if } \mathrm{HDD} \geq 0 \\
0 \text { if } \mathrm{HDD}<0
\end{array}\right. \\
& \text { CRUDEPR is the average imported refiners acquisition cost of } \\
& \text { crude oil deflated by the Producer Price Index. } \\
& \text { STOCKDIF is the deviation of the current stock level from the } \\
& \text { average of the previous } 3 \text { years. } \\
& \text { TREND is a linear trend line. } \\
& \text { DEMAND is the distillate product supplied. } \\
& \text { IPIDIF is the deviation from a normalized industrial } \\
& \text { production index }{ }^{2} \text {. } \\
& \text { DUMMY }_{i} \text { are monthly dummy variables. } \\
& \text { DOAUG90 are dummy variables for August, 1990, and December, } \\
& \text { DODEC90 1990, respectively. } \\
& t \text { is the subscript variable for monthly time series } \\
& \text { observations. }
\end{aligned}
$$

The inputs to the above equations are exogenous (i.e. STEO estimated) or previously calculated values for the variables. Direct output from these equations consist of 1-month-ahead forecasts of PRICE and DEMAND for total distillate fuel oil. The determination of the 1-month-ahead stock level from the forecasted level of demand is calculated by the following formulas:

$$
\begin{aligned}
& \text { DELSTOCK }_{t}=\left(\text { PRIM_SUP }_{t}-\text { DEMAND }_{t}\right) \star \text { DAYS }_{t} \\
& \text { STOCK }_{t}=\text { STOCK }_{t-1}+\text { DELSTOCK } \\
& \text { STOCKDIF }_{t}=\text { STOCK }_{t}-\text { STOCKAVG }_{t}
\end{aligned}
$$

where PRIM_SUP is the sum of refinery output and net imports of distillate fuel oil (from STEO).

DAYS is the number of days in month $t$.

STOCKAVG is $\left(\right.$ STOCK $_{t-12}+$ STOCK $_{t-24}+$ STOCK $\left._{t-36}\right) / 3$

STOCK is the end-of-month stock level for total No. 2 distillate.

\footnotetext{
${ }^{2}$ IPIDIF $_{t}=$ IPI $_{t}-$ IPIN $_{t}$, where IPIN $_{t}$ is the detrended industrial production index for the January, 1986, through December, 1994, time frame.
} 


\section{PROPERTIES OF MATHEMATICAL SOLUTION}

\section{Theoretical Considerations}

The model is a standard demand-supply set of equations with no contemporaneous direct dependence between the demand and price equations. Any possible problem of simultaneous equations bias was addressed by formulating the model as a set of recursive equations with unidirectional indirect dependency among the dependent variables. The first endogenous variable, viz. demand, is determined only by exogenous variables; the second endogenous variable, viz. price, is determined by exogenous and predetermined variables. There is indirect feedback from the demand equation to the price equation through the lagged stock variable; the lack of a direct feedback from demand to price implies that a disturbance to the demand equation does not affect the price equation. Thus there is no contemporaneous correlation between the demand equation and price, so that Ordinary Least square (OLS) estimate is unbiased (P. Kennedy, 1985).

Certain a priori restrictions were placed on the domain of a number of variables. These include:

- The lag-one autocorrelation parameter of the model has a domain between -1 and +1 ;

- The elasticity of demand is between 0 and -1 ; the elasticity of supply is greater than zero;

- The price, demand and stock level are finite and greater than zero.

\section{Subject Matter Considerations}

The original purpose of the DMM was to model the retail No. 2 fuel oil market at the national level. Data limitations required expanding the focus so as to include the market for total No. 2 distillate (i.e., heating fuel oil plus diesel fuel). The DMM assumes that market reactions are based on recent historical patterns and that any behavioral effects due to increased market segmentation as a result of the introduction of low sulfur and low aromatic diesel fuels will be incremental. While the annual incorporation of current data with historical trends may affect the DMM's responsiveness, minor structural changes in the market can be accommodated with modifications to the equations. The domain of the input variables is assumed to be that of the recent historical time series for the individual variables. Preliminary studies at the Petroleum Marketing Division have shown that equations with similar structure can also be used to describe the market functions within certain Petroleum Administration for Defense (PAD) Districts. 


\section{CALIBRATION AND SENSITIVITY ANALYSIS}

\section{Results of Calibration}

Calibration of the model was performed using a comparison of the forecasts for demand, retail price and end-of-month stock level obtained by the DMM with those obtained by STIFS (third quarter, 1993 STEO) for the period June, 1993, through March, 1994. The following three tables illustrate the comparison values. It should be noted that the DMM endof-month stock values for the first 2 months (i.e., June and July) reported in the tables were estimated from actual data ${ }^{3}$.

NO. 2 DISTILIATE OUTLOOK: DEMAND Comparison of STEO and DMM Forecasts

\begin{tabular}{|c|c|c||}
\hline DATE & $\begin{array}{c}\text { STEO } \\
(\text { MMbbl/d })\end{array}$ & $\begin{array}{c}\text { DMM } \\
(\text { MMbbl/d) }\end{array}$ \\
\hline \hline Jun-93 & 2836 & 2855 \\
\hline Jul-93 & 2700 & 2717 \\
\hline Aug-93 & 2864 & 2812 \\
\hline Sep-93 & 2922 & 2885 \\
\hline Oct-93 & 3134 & 3103 \\
\hline Nov-93 & 3165 & 3119 \\
\hline Dec-93 & 3445 & 3466 \\
\hline Jan-94 & 3606 & 3523 \\
\hline Feb-94 & 3590 & 3534 \\
\hline Mar-94 & 3585 & 3461 \\
\hline
\end{tabular}

${ }^{3}$ The tabulated values were estimated from a linear interpolation of weekly data published in the Weekly Petroleum Status Report, DOE/EIA-0208, various issues. 
NO. 2 DISTILLATE OUTLOOK: STOCKS

Comparison of STEO and DMM Forecasts

\begin{tabular}{||c|c|c||}
\hline DATE & $\begin{array}{c}\text { STEO } \\
(\mathrm{MMbb1})\end{array}$ & $\begin{array}{c}\text { DMM } \\
(\mathrm{MMBb} 1)\end{array}$ \\
\hline \hline Jun-93 & 106.2 & 109.1 \\
\hline Jul-93 & 117.1 & 120.4 \\
\hline Aug-93 & 121.6 & 126.5 \\
\hline Sep-93 & 127.5 & 133.5 \\
\hline Oct-93 & 130.5 & 137.4 \\
\hline Nov-93 & 137.0 & 145.3 \\
\hline Dec-93 & 136.5 & 144.1 \\
\hline Jan-94 & 130.0 & 140.2 \\
\hline Feb-94 & 117.0 & 128.7 \\
\hline Mar-94 & 101.7 & 117.3 \\
\hline
\end{tabular}

NO. 2 DISTILLATE OUTLOOK: RETAIL PRICE Comparison of STEO and DMM Forecasts

\begin{tabular}{||c|c|c|}
\hline DATE & $\begin{array}{c}\text { STEO } \\
\text { (cents/gal) }\end{array}$ & $\begin{array}{c}\text { DMM } \\
\text { (cents/gal) }\end{array}$ \\
\hline \hline Jun-93 & 90.2 & 88.2 \\
\hline Jul-93 & 88.4 & 85.9 \\
\hline Aug-93 & 88.1 & 86.1 \\
\hline Sep-93 & 89.6 & 88.0 \\
\hline Oct-93 & 93.5 & 90.9 \\
\hline Nov-93 & 96.3 & 93.7 \\
\hline Dec-93 & 99.7 & 96.5 \\
\hline Jan-94 & 100.1 & 97.6 \\
\hline Feb-94 & 98.6 & 95.9 \\
\hline Mar-94 & 97.2 & 94.9 \\
\hline
\end{tabular}


Another calibration was done by using the DMM to perform a dynamic ex post forecast of distillate price and demand for the previous heating season (i.e., 199204 and 1993Q1). The results are shown in the next two tables, along with the actual values and the STIFS projections for the same time period. It can be seen that the accuracy of the DMM values compare favorably to those generated by STIFS.

NO. 2 DISTILIATE EX POST FORECAST: PRICE

Comparison of Model Predictions with Actual Values

(Cents per Gallon)

\begin{tabular}{||c|c|c|c|c||}
\hline DATE & SERIES & ACTUAL & DMM & STEO \\
\hline $\begin{array}{c}4 \text { tharter } \\
1992\end{array}$ & Value & 94.4 & 91.8 & 94.1 \\
\hline & $\begin{array}{c}\text { Deviation } \\
\text { from Actual }\end{array}$ & & -2.6 & -0.3 \\
\hline $\begin{array}{c}\text { 1st } \\
\text { Quarter, } \\
1993\end{array}$ & Value & 94.8 & 94.2 & 93.9 \\
\hline & $\begin{array}{c}\text { Deviation } \\
\text { from Actual }\end{array}$ & & -0.6 & -0.9 \\
\hline
\end{tabular}

NO. 2 DISTILLATE EX POST FORECAST: DEMAND

Comparison of Model Predictions with Actual Values

(Million Barrels per Day)

\begin{tabular}{||c|c|c|c|c|}
\hline DATE & SERIES & ACTUAL & DMM & STEO \\
\hline $\begin{array}{c}4 \text { tharter } \\
1992\end{array}$ & Value & 3.10 & 3.21 & 3.26 \\
\hline & $\begin{array}{c}\text { Deviation } \\
\text { from Actual }\end{array}$ & & +0.11 & +0.16 \\
\hline $\begin{array}{c}1 \text { 1st } \\
\text { Quarter, } \\
1993\end{array}$ & Value \\
\hline & $\begin{array}{c}\text { Deviation } \\
\text { from Actual }\end{array}$ & 3.30 & 3.44 & 3.54 \\
\hline
\end{tabular}




\section{Model Runs to Test Concordance with Intuition}

The DMM underwent two tests to determine its correspondence with intuition and economic theory. This test was performed by increasing the severity of a prolonged cold snap during the heating season and was done in two parts: (1) the Cold Heating Season case, which increases the total mean heating degree days during the october through March season by 10 percent over the normal amount, and (2) the cold winter case, which takes the same number of increased mean heating degree days and apportions this amount just over the winter (i.e., January through March) months. Since one of the principal uses of No. 2 fuel oil is for residential and industrial heating, the results of this test should show that during the period of colder temperatures, demand for distillate will increase over and above that in the base case. The increased demand would create a larger demand/supply imbalance, thus putting additional upward pressure on prices, and would also result in larger stock drawdowns. This expected pattern of market behavior emulates that described in the EIA Service Report entitled "An Analysis of Heating Fuel Market Behavior, 1989-90", which provides an ex post analysis of a severe 1-month cold snap.

The following tables show the DMM's behavior under these scenarios and demonstrates the models' concordance with intuition. The model predicts that both the demand and retail price of distillate will rise, beginning in the first month of the beginning of the cold snap.

NO. 2 FUEL OIL SCENARIOS: DEMAND

Impact of Alternative Scenario Assumptions (Thousand Barrels per Day)

\begin{tabular}{|c|c|c|c|}
\hline DATE & BASE CASE & $\begin{array}{c}\text { COLD HEATING } \\
\text { SEASON }\end{array}$ & $\begin{array}{c}\text { COIDD } \\
\text { WINTER }\end{array}$ \\
\hline Aug-93 & 2812 & 2812 & 2812 \\
\hline Sep-93 & 2885 & 2885 & 2885 \\
\hline Oct-93 & 3103 & 3142 & 3103 \\
\hline Nov-93 & 3119 & 3206 & 3119 \\
\hline Dec-93 & 3466 & 3599 & 3466 \\
\hline Jan-94 & 3523 & 3679 & 3754 \\
\hline Feb-94 & 3534 & 3679 & 3777 \\
\hline Mar-94 & 3461 & 3572 & 3648 \\
\hline
\end{tabular}


NO. 2 FUEL OIL SCENARIOS: RETAIL PRICE

Impact of Alternative Scenario Assumptions (Cents per Gallon)

\begin{tabular}{|c|c|c|c||}
\hline DATE & BASE CASE & $\begin{array}{c}\text { COLD HEATING } \\
\text { SEASON }\end{array}$ & $\begin{array}{c}\text { COLD } \\
\text { WINTER }\end{array}$ \\
\hline Aug-93 & 86.1 & 86.1 & 86.1 \\
\hline Sep-93 & 88.0 & 88.0 & 88.0 \\
\hline Oct-93 & 90.9 & 91.1 & 90.9 \\
\hline Nov-93 & 93.7 & 94.6 & 93.7 \\
\hline Dec-93 & 96.5 & 99.0 & 96.5 \\
\hline Jan-94 & 97.6 & 101.8 & 103.4 \\
\hline Feb-94 & 95.9 & 100.5 & 106.9 \\
\hline Mar-94 & 94.9 & 98.7 & 103.2 \\
\hline
\end{tabular}

NO. 2 FUEL OIL SCENARIOS: STOCK LEVEL Impact of Alternative Scenario Assumptions (Millions of Barrels)

\begin{tabular}{|c|c|c|c||}
\hline DATE & BASE CASE & $\begin{array}{c}\text { COLD HEATING } \\
\text { SEASON }\end{array}$ & $\begin{array}{c}\text { COLD } \\
\text { WINTER }\end{array}$ \\
\hline Aug-93 & 126.5 & 126.5 & 126.5 \\
\hline Sep-93 & 133.5 & 133.5 & 133.5 \\
\hline Oct-93 & 137.4 & 136.2 & 137.4 \\
\hline Nov-93 & 145.3 & 141.5 & 145.3 \\
\hline Dec-93 & 144.1 & 136.2 & 144.1 \\
\hline Jan-94 & 140.2 & 127.4 & 133.0 \\
\hline Feb-94 & 128.7 & 111.9 & 114.8 \\
\hline Mar-94 & 117.3 & 97.0 & 97.6 \\
\hline
\end{tabular}




\section{DOCUMENTATION OF TECHNICAL DETAIL ON MODEL DATA AND EQUATIONS}

\section{Validation of Input Data}

Input variables that the DMM has in common with the STIFS were used with identical values.

\section{Non-DOE Input Sources:}

- Data Resources, Inc. (DRI) database, data from Bureau of Economic Analysis and Bureau of Labor Statistics.

- Macroeconomic production and price index data.

- U.S. Department of Commerce, National Oceanographic and Atmospheric Administration, Data Source DRD $964 \mathrm{X}$.

- Actual and normal statewide monthly heating degree day values.

\section{DOE Data Input Sources:}

\section{Forms and Publications:}

- Energy Information Administration, Petroleum Supply Annual, DOE/EIA0340 and Petroleum Supply Monthly, DOE/EIA-0109, various issues.

- No. 2 Distillate stocks and product supplied.

- Energy Information Administration, Petroleum Marketing Annual, DOE/EIA-0487 and Petroleum Marketing MonthIy, DOE/EIA-0380, various issues.

- Average imported crude oil refiner's acquisition costs, No.2 fuel oil prices to residential customers.

\section{Models and Other:}


Energy Information Administration, Short-Term Integrated Forecasting System.

- Forecasts of economic and refinery variables.

\section{Validation, Goodness-of-Fit of Equations Providing Parameter Estimates}

The next table details the parameter estimates and a number of statistics related to the goodness-of-fit of the equations estimated by the DMM. 


\section{REGRESSION RESULTS}

Dependent Variable is PRICE

SAMPLE RANGE: 1986.01 - 1993.05

Number of Observations: 89

Convergence achieved after four iterations

\begin{tabular}{|c|c|c|c|c|c|}
\hline VARIABLE & \multicolumn{2}{|c|}{ COEFFICIENT } & STD. ERROR & T-STAT & Prob $>|\mathrm{T}|$ \\
\hline $\mathrm{C}$ & \multicolumn{2}{|c|}{45.497756} & 2.9950765 & 15.1908 & 0.0000 \\
\hline $\operatorname{STOCKDIF}(-1)$ & \multicolumn{2}{|c|}{$-6.143 E-05$} & $2.725 E-05$ & -2.2549 & 0.0272 \\
\hline HDDSPSQ & \multicolumn{2}{|c|}{0.1850852} & 0.0208315 & 8.8849 & 0.0000 \\
\hline $\operatorname{HDDSPSQ}(-1)$ & \multicolumn{2}{|c|}{0.1831785} & 0.0219738 & 8.3362 & 0.0000 \\
\hline CRUDEPR & \multicolumn{2}{|c|}{1.1098742} & 0.1524691 & 7.2793 & 0.0000 \\
\hline CRUDEPR $(-1)$ & \multicolumn{2}{|c|}{0.6629819} & 0.1537608 & 4.3118 & 0.0001 \\
\hline JAN & \multicolumn{2}{|c|}{8.6722380} & 1.0102065 & 8.5846 & 0.0000 \\
\hline FEB & \multicolumn{2}{|c|}{8.3931833} & 0.9752726 & 8.6060 & 0.0000 \\
\hline MAR & \multicolumn{2}{|c|}{7.8248503} & 0.9257423 & 8.4525 & 0.0000 \\
\hline APR & \multicolumn{2}{|c|}{6.1509881} & 0.851 .8563 & 7.2207 & 0.0000 \\
\hline MAY & \multicolumn{2}{|c|}{4.0395809} & 0.7461252 & 5.4141 & 0.0000 \\
\hline JUN & \multicolumn{2}{|c|}{1.8900819} & 0.5575943 & 3.3897 & 0.0011 \\
\hline AUG & \multicolumn{2}{|c|}{0.0814093} & 0.5764404 & 0.1412 & 0.8881 \\
\hline SEP & \multicolumn{2}{|c|}{1.4885528} & 0.7766028 & 1.9167 & 0.0593 \\
\hline OCT & \multicolumn{2}{|c|}{2.8447527} & 0.9052433 & 3.1425 & 0.0024 \\
\hline NOV & \multicolumn{2}{|c|}{4.5557712} & 0.9751640 & 4.6718 & 0.0000 \\
\hline $\mathrm{DEC}$ & \multicolumn{2}{|c|}{6.9728389} & 1.0207939 & 6.8308 & 0.0000 \\
\hline $\mathrm{AR}(1)$ & 0.9 & 5744 & 0.0437259 & 21.2591 & 0.0000 \\
\hline R-squared & & 0.97362 & Mean of $d$ & vendent var & 79.6016 \\
\hline Adjusted R-sq & red & 0.96730 & Sum of $\mathrm{sq}$ & red resid & 157.515 \\
\hline S.E. of regres & ion & $1.4894^{\circ}$ & F-statist & & 154.128 \\
\hline Durbin-Watson & tat & 1.56169 & Prob (F-st & istic) & 0.00000 \\
\hline
\end{tabular}


Dependent Variable is DEMAND

SAMPLE RANGE: 1986.01 - 1993.05

Number of Observations: 89

\begin{tabular}{|c|c|c|c|c|c|}
\hline VARIABLE & \multicolumn{2}{|c|}{ COEFFICIENT } & STD. ERROR & T-STAT & Probs $|\mathrm{T}|$ \\
\hline C & \multicolumn{2}{|c|}{2621.3756} & 42.624147 & 61.4998 & 0.0000 \\
\hline IPIDIF & \multicolumn{2}{|c|}{2697.9939} & 471.10898 & 5.7269 & 0.0000 \\
\hline $\mathrm{HDD}$ & \multicolumn{2}{|c|}{45.352706} & 6.9123506 & 6.5611 & 0.0000 \\
\hline $\operatorname{HDD}(-1)$ & \multicolumn{2}{|c|}{6.9906104} & 6.7522263 & 1.0353 & 0.3040 \\
\hline TREND & \multicolumn{2}{|c|}{1.1094102} & 0.4431797 & 2.5033 & 0.0146 \\
\hline DOAUG90 & \multicolumn{2}{|c|}{418.11904} & 110.05244 & 3.7993 & 0.0003 \\
\hline DODEC9O & \multicolumn{2}{|c|}{-471.86726} & 111.92963 & -4.2157 & 0.0001 \\
\hline JAN & \multicolumn{2}{|c|}{766.73046} & 55.002384 & 13.9399 & 0.0000 \\
\hline FEB & \multicolumn{2}{|c|}{768.15699} & 55.555109 & 13.8269 & 0.0000 \\
\hline MAR & \multicolumn{2}{|c|}{687.59673} & 54.156485 & 12.6965 & 0.0000 \\
\hline APR & \multicolumn{2}{|c|}{326.27238} & 53.358360 & 6.1147 & 0.0000 \\
\hline MAY & \multicolumn{2}{|c|}{162.69299} & 52.676103 & 3.0886 & 0.0029 \\
\hline JUN & \multicolumn{2}{|c|}{143.59998} & 54.259416 & 2.6465 & 0.0100 \\
\hline AUG & \multicolumn{2}{|c|}{89.529303} & 56.402450 & 1.5873 & 0.1169 \\
\hline SEP & \multicolumn{2}{|c|}{154.61078} & 54.198330 & 2.8527 & 0.0057 \\
\hline OCT & \multicolumn{2}{|c|}{366.06589} & 54.476738 & 6.7197 & 0.0000 \\
\hline NOV & \multicolumn{2}{|c|}{377.16468} & 54.544196 & 6.9184 & 0.0000 \\
\hline $\mathrm{DEC}$ & \multicolumn{2}{|c|}{716.88629} & 56.567173 & 12.6732 & 0.0000 \\
\hline \multicolumn{2}{|l|}{ R-squared } & 0.90116 & \multicolumn{2}{|c|}{ Mean of dependent var } & 3027.42 \\
\hline \multicolumn{2}{|c|}{ Adjusted R-squared } & 0.87749 & \multicolumn{2}{|c|}{ Sum of squared resid } & 289.550 \\
\hline \multicolumn{2}{|c|}{ S.E. of regression } & 101.345 & \multicolumn{2}{|c|}{ F-statistic } & 38.0779 \\
\hline \multicolumn{2}{|c|}{ Durbin-Watson stat } & 1.94 & \multicolumn{2}{|c|}{$\operatorname{Prob}(\mathrm{F}$-statistic) } & 0.00000 \\
\hline
\end{tabular}




\section{BIBLIOGRAPHY}

Energy Information Administration, Short-Term Integrated Forecasting System, 1993 Model Documentation Report, DOE/EIA-MO41(93), Washington, DC., 1993.

Energy Information Administration, An Analysis of Heating Fuel Market Behavior in 1989-90, Service Report, SR/OG/90-01, Washington, DC., 1993.

P. Kennedy, A Guide To Econometrics, 2nd Edition, MIT Press, Cambridge, Massachusetts, 1985.

R. J. Southerland, "An Analysis of Heating Fuel Prices During the Winter of 1989-90", Energy System and Policy, Vol. 15, pp. 161-180, 1991. 
Model Name: Distillate Market Model

Model Acronym: DMM

Model Description: The DMM performs a short-term (6- to 9-month) forecast of demand and price in the U.S. No. 2 fuel oil market. The model also calculates the end-of-month stock level. The model is used to analyze certain market behavior assumptions or market shocks and to determine their effect on market price, demand and stocks.

Last Mode1 Update: September, 1993.

Part of Another Model: None.

Model Interfaces: None. The DMM uses inputs from STIFS, from which it obtains Economic and Refinery Data.

\section{Sponsor :}

Office: Office of Oil and Gas

Division: Petroleum Marketing Division

Branch: Publications and Analysis, EI-432

Model Contact: Charles Dale

Telephone: (202) 586-1805.

Documentation: Energy Information Administration, Model Documentation of the Distillate Activity Market Model, DOE/EIA-M056, (Washington, DC, September, 1993).

Archive Media and Installation Guides: Archived on floppy disks, with internal documentation. Available from sponsoring office. Archive packages describing the use of the model in published applications may be obtained from:

National Technical Information Service 5285 Port Royal Road

Springfield, Virginia 22161 
Purpose: The Distillate Market Model was developed to provide support for the annual "Distillate Outlook" article published in the Winter Fuels Report and the Petroleum Marketing Monthly. The DMM assesses the market response to alternative market scenarios and/or shocks. The model relies on the STIFS mid-world oil price case for values of economic and refinery behavior variables to define a base-line and then uses assumptions on different possible market disturbances to assess their effects on a monthly basis. The DMM provides a framework to calculate stock levels from the estimated demand and price variables.

Energy System Described by Model: No. 2 distillate demand, retail prices and end-of-month stock levels.

\section{Coverage:}

- Geographic: National

- Time Unit/Frequency: Monthly

- Products: No. 2 Distillate Fuel Oil

- Economic Sector: Retail No. 2 Distillate Market.

\section{Modeling Features :}

- Model Structure: Multi-equation model

- Modeling Technique: Ordinary least squares, with correction for autocorrelation

- Special Features: None.

\section{Non-DOE Input Sources:}

- Data Resources, Inc. (DRI) database, data from Bureau of Economic Analysis and Bureau of Labor Statistics

- Macroeconomic production, and price index variables

- U.S. Department of Commerce, National Oceanographic and Atmospheric Administration, Data Source DRD $964 \mathrm{X}$

- Actual and normal statewide monthly heating degree day values. 
DOE Data Input Sources:

Forms and Publicatiors:

- Energy Information Administration, Petroleum Supply Annual, DOE/EIA-0340 and Petroleum Supply Monthly, DOE/EIA-0109

- No. 2 distillate stocks and product supplied

- Energy Information Administration, Petroleum Marketing Annual, DOE/EIA-0487 and Petroleum Marketing Monthly, DOE/EIA-0380

- Average imported crude oil refiner's acquisition costs, residential No. 2 fuel oil prices.

Models and Other:

- Energy Information Administration, Short-Term Inteqrated Forecasting System

- Forecasts of economic and refinery variables.

General Output Descriptions: DMM is used to generate very short-term (up to 9 months), monthly forecasts of U.S. demand, price and stock levels of retail no. 2 distillate.

\section{Computing Environment:}

- Hardware Used: IBM-compatible personal computer

- Operating System: MS DOS

- Software Used: Micro-TSP, Version 7.01 or higher

- Memory Requirements: $640 \mathrm{~K}$

- Storage Requirements: $640 \mathrm{~K}$

- Estimated Run Time: 30 seconds calculation time on an 80386 PC operating under DOS 5

- Special Features: None.

Independent Expert Reviews: None.

Status of Evaluations by Sponsor: On-going. Annual revisions will be made based on needs of users. 


\section{References}

Energy Information Administration, Short-Term Integrated Forecasting System, 1993 Model Documentation Report, DOE/EIA-M041(93), Washington, DC., 1993.

Energy Information Administration, An Analysis of Heating Fuel Market Behavior in 1989-90, Service Report, SR/OG/90-01, Washington, DC., 1990 .

R. J. Southerland, "An Analysis of Heating Fuel Prices During the Winter of 1989-90", Energy System and Policy, Vol. 15, pp. 161-180, 1991. 


\section{Model Cross Reference}

\section{Equations}

(Pages 6-7)

DEMAND

PRICE

DELSTOCK

STOCK

STOCKDEL

\section{Variable Name}

PRICE

CRUDEPR

DEMAND

HDD

HDDSPSQ

IPIDIF

TREND

DUMMYY

DOAUG90

DODEC 90

DELSTOCK

STOCK

PRIM_SUP

DAYS

STOCKDIF

STOCKAVG
Name in Code

PRICE

CRUDEPR

DEMAND

HDD

HDDSPSQ

IPIDIF

TREND

JAN, MAR, etc.

DUAUG90

DODEC 90

DELSTOCK

STOCK

PRIM_SUP

DAYS

STOCKDIF

STOCKAVG
Location in Code (Line Numbers)

$1-4$

$5-8$

9

10

11

\section{Location in Code}

5

6

1,9

1

5

1

1

$2-4,5-8$

2

2

9,10

10,11

9

9

5,11

11 


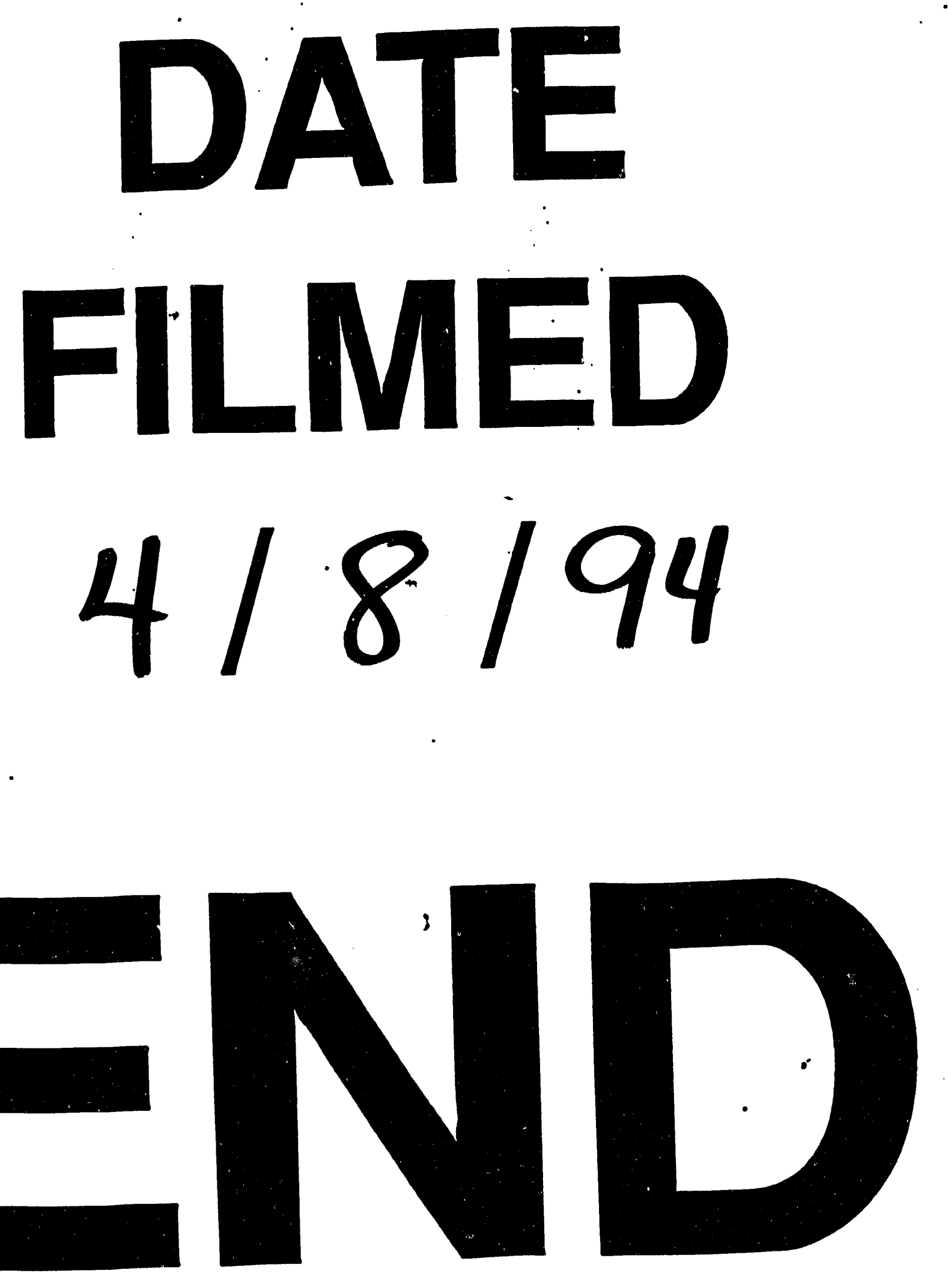




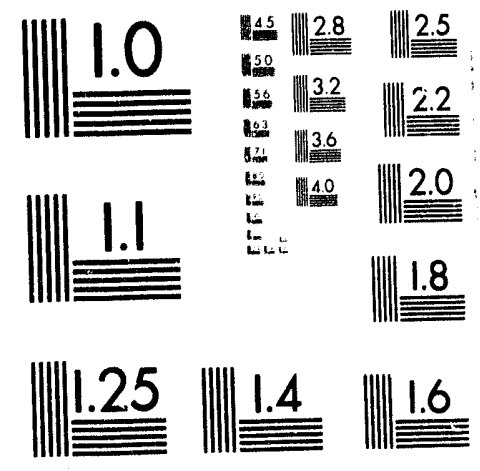

